\title{
Academic Identities and Institutional Aims: Critical Discourse Analysis of Neoliberal Keywords on U15 University Websites
}

\author{
Sandra Kouritzin ${ }^{1}$, Satoru Nakagawa ${ }^{1}$, Erika Kolomic ${ }^{1} \&$ Taylor F. Ellis ${ }^{1}$ \\ ${ }^{1}$ Faculty of Education, University of Manitoba, Manitoba, Canada \\ Correspondence: Sandra Kouritzin, PhD, Professor, Curriculum, Teaching and Learning, Faculty of Education, \\ University of Manitoba, Manitoba, Canada.
}

Received: June 21, 2020

Accepted: October 14, 2020

Online Published: October 20, 2020

doi:10.5430/irhe.v5n3p8

URL: https://doi.org/10.5430/irhe.v5n3p8

\begin{abstract}
Through their websites, universities establish global identities, enabling them to persuade potential students, partners, and research funders of their international prestige, relevance, and unique positioning to prepare students for competition in the global marketplace. They do so through forms of branding such as logos, slogans, images and texts intended to attract potential students, funders and partners. Addressing how website texts construct academic identities and reveal institutional aims, through critical discourse analysis, this paper examines textual discourses found on Canadian U15 Group of Universities' websites. We focus specifically on how seemingly common-sense keywords are actually rich in ideological and socio-historical meaning. After identifying keywords and concepts across U15 websites, we determined that five themes dominated: University as a corporate entity, University as machine or vehicle, aspirational academic identities, market metaphors, and the doctrine of discovery. Noting the similarities in promotional discourses found across research-intensive university websites, we suggest that university websites communicate and foster neoliberal discourses, ideologies, values, and identities, thereby aligning universities with the values associated with consumer and petro-capitalism rather than with the traditional university ideals of intellectual pursuit, knowledge creation, disciplinary wisdom, good teaching and rigorous scholarship.
\end{abstract}

Keywords: university, promotional discourse, websites, neoliberalism, ideology

As language teacher/researchers and applied linguists, we know that learning new words can create a Baader-Meinhof frequency illusion as words previously unknown seem to pop up in daily life with alarming frequency. As academics examining the impact of neoliberalism on workload in the university (Kouritzin, 2019), however, we have come to doubt that this is simply cognitive bias at work; once you learn to listen for the language of neoliberalism-the sharp, slick market-based jargon that has become the tongue of choice for those who hold or seek access to the corridors of power-it truly is all around.

Donning our critical lenses, we peruse Canadian U15 Group of research-intensive University websites: "As [the province's] only research-intensive university, we fuel the local economy." Websites promise that students will "become entrepreneurial thinkers and change agents through education," who will "transfer our research discoveries and innovations out of the university via commercialization" to ensure that "our research has the greatest reach and impact for society and the economy." University researchers "communicate knowledge in innovative ways, employing cutting-edge methodologies," and "fuel innovation with their expertise, generating wealth in [each] province." Perhaps most cringeworthy of all, researchers "fuel research" that both "create valuable products" and "liberate the oil locked in Alberta's oilsands."

These buzzwords, or "vocabularies of the economy" (Massey, 2013) are markers of the hegemony of neoliberal ideology, acting to redefine "roles, identities and relationships - of people, places and institutions", manifested and reinforced in embodied practices, and thereby imposing "the ideology of neoliberalism, and thus a new capitalist hegemony" (p.11) on all of us. Holborrow (2015) too draws on Gramsci's (1971) work to examine expressions of neoliberalism in language use as both reflecting and reinforcing hegemonic thought structures. She notes that, linguistically, Gramsci's concept of common sense, in which expressions of a particular order of the world being natural are legitimized through discourse, reflects the idea that "our 'unthinking' engagement in language can often appear to accept uncritically its ideological meanings" (p.4). She draws on the example of the neoliberal keyword entrepreneur, first exploring the historical meanings of the word as directly tied to an individual's establishment of a 
business and the corresponding sense of risk, then examining how fluctuations over time in corresponding synonyms and usage emphasize the concepts of boldness and pursuit of wealth. Entrepreneur, she suggests, "encapsulates a social imaginary in which individuals are centre stage, wealth is understood in individual terms and wealth-seeking individuals are the role models" (p.72); its usage in seemingly inappropriate contexts points to a shift from interactions to transactions in all aspects of social life. Language is, she notes, "part of the ideological glue of the neoliberal narrative" (p.71).

\section{Literature Review}

The university-by which we signify the idea of a university as a social institution rather than a particular institutionis a site of interest for the examination of both the linguistic and ideological neoliberal drift in that it has historically represented a space for critical examination and dissemination of ideas. Somewhat paradoxically, it has become infected with what Smyth (2017) terms the "alien" ideology of neoliberalism (p.7), and subsequently redefined as entrepreneurial, concerned with the pursuit of profit and characterised by the managerial trappings of the business world (Peters, 2013). The websites cited above present a window into the phenomenon of this redefined university: the relentless drive to make graduates ready for the workforce as the basis for all educative endeavours, the inspiring promise of the individual innovator - represented by glossy, brightly coloured headshots of students or faculty, often alone, staring upwards and into the distance - and the use of research and research products as tools for institutional self-promotion and profit. That is, through their websites, universities establish global identities enabling them to persuade potential students, partners, and research funders of their international prestige and relevance.

Sachaie (2011), in an analysis of university websites in the United States, suggested that universities are similar in the approaches they use on their websites. All of them try to establish, through the language they use, the power and prestige of their researchers, faculty, and staff, thereby rationalizing the relevancy of their programs. Through carefully chosen language and images, universities make a case for institutional legitimacy, and their unique ability to propel graduates into professional workplaces. At the same time, however, the language and images used to promote universities are remarkably similar.

Similar to Sachaie (2011), Huang and Rojas-Lizana (2015) suggest that Australian university websites are purposefully designed to attract potential students, showing themselves unique through forms of branding such as logos, slogans, images and text to attract potential students. University websites use language strategically to sell their products while simultaneously differentiating themselves from their competitors. Ihme et al (2016) investigated whether or not images and information appealing to diverse age groups would impact student decision-making to attend a specific university, concluding that it would. Consequently, universities expend enormous human and financial resources on readable and functional website construction and maintenance (Kimmons, 2017), in order to establish themselves as entrepreneurs and competitors. Nonetheless, Verkijika \& De Wet (2020) found that none of the 26 universities they analysed met the basic criteria for accessibility, establishing that only certain students are their audience.

The competition for students is both monetary and the currency of public image (Holborow, 2015). Labour-and academic identity-is commodified, valued in terms of competition value to the organization; therefore, academics are expected to engage in "competitive entrepreneurialism" (Gildersleeve, 2017, p.287) such as constant becoming: re-training, networking and maximizing their research output as a means of self-marketing (Kouritzin, et al., forthcoming). Furthermore, education itself is "rendered a consumer good in which students invest (often by incurring considerable debt) to advance their own prospects" (Smyth, 2017, p.31); therefore, students must compete for entry to the most prestigious institutions to guarantee their own success. This logic transforms the labourteaching and research-that occurs within universities, by transforming teaching into a consumeristic exchange and the mobilization of research "outputs" a commercial endeavour (Ball, 2012; Chatterton, Hodkinson, \& Pickerill, 2010; Peters, 2013; Smyth, 2017; Sutton, 2017; Tuchman, 2009). The result is a relational shift in what it means to be an academic within these institutions. Gildersleeve (2017) argues that academics, while still believing in the social contract between universities and society to safeguard knowledge and protect it from political influence, are obliged to engage in activities antithetical to their own beliefs about their work, such as finding new markets for capitalist exploitation, engendering partnerships with private enterprises, and otherwise transforming knowledge into conveniently-packaged commodities to be sold in global markets.

We suggest that there is a need to examine how this shift at the collective level is reflected and recreated in individual institutions, in this case with reference to university websites. Having found no examinable large-scale differences among websites in the U15, we examine the following research questions: 
(1) How do the discourse strategies of U15 university websites reflect academic identities and institutional aims?

(2) What can be extrapolated from linguistic analysis of the U15 university websites with regard to views about the purposes of higher education, and ideological and socio-political values?

\section{Method}

Hoang and Rohas-Lizana (2015) note that despite the importance of university websites as both recruitment and promotional tools, there is a surprising "lack of research investigating the language used by universities on their websites" (p.3). In response, as one aspect of our Social Sciences and Humanities Research Council Insight Grant examining workload in the U15, we here review websites for universities who are members of the Canadian U15 (http://u15.ca/) Group of research-intensive universities captured in the months of August to November 2019. Because websites change frequently, we adopted this limited approach, but not as limited as Jawitz and Williams (2015) who (needlessly) limited themselves to a single day. While each website was structured somewhat differently, an effort was made to focus on particular sections/strands of each website that would offer a basis for comparison and would fit with the focus on academic identities and institutional aims. To this end, for example, website sections listing faculties/departments or degree requirements or focused on campus amenities for students were not included.

The review of each website began by locating and examining pages related to the overall brand/identity of the university, often describing the university's mission statement, goals, and strategic plan (Kouritzin, et al., forthcoming). This process was non-linear; the embedded design of websites led us to open new pages for later review. It also often involved downloading and reading related content and documents that were linked on the website. Following this, we reviewed website sections related directly to research. One important consideration is that several universities had "business accelerators" or "entrepreneurship hubs" to facilitate the commercialization of research; these agencies/groups/ventures were often affiliated but not officially part of the university. As the work of these agencies is connected to the work of academics within the university, these websites were at times included in the survey when the content was deemed to connect with academic work/identity. During the initial collection and analysis of the quotations by institution, we represented the original context of each quotation, bolding keywords that would serve the later thematic analysis. We later narrowed our focus as themes were established.

The U15 universities have been chosen for analysis because they are a useful case study given their distribution across all of Canada's various geographic regions: West Coast (U British Columbia), Prairies (U of Alberta, U of Calgary, $U$ of Saskatchewan, and $U$ of Manitoba), Ontario ( $U$ of Toronto, University of Waterloo, McMaster University, University of Western Ontario, Queen's University, and uOttawa), Québec (McGill University, UQAM, and Université Laval), and the Maritimes (Dalhousie University). One of the features of the neoliberal construction of the university website is conformance to particular conventions of self-promotion (e.g., Kouritzin, et al., forthcoming; in review). Such isomorphism has been observed in analysis of university websites in Australia and the United States (Hoang \& Rojas-Lizana, 2015; Saichaie, 2011); our critical discourse analysis identifies a similar pattern of neoliberal self-promotion within Canadian higher education, but our analysis is more detailed. While for reasons of space we are unable to discuss all of the keywords in each category, we provide our highlighted tables to enable readers to engage with additional findings. Our tables only give examples of the keywords and phrases as they appear in context. They are not exclusive in that one example may support a number of themes.

\section{Keywords: Markets, Machines and Multinationalisms}

The ideologically-laden language we identified appears to highlight the reconstruction of the university within the discursive neoliberal market-supremacy (Holborow, 2015). Examples were categorised into the following emergent themes, each presented within a table with multiple examples: University as a corporate entity, academic identities of students and faculty, mechanisation of university functions and goals, deference to the market as metaphor, and the doctrine of discovery. Not only do the keywords within each of these themes respond to specific social, political, and economic pressures facing higher education, but they also serve a particular function in order to collectively promote neoliberalism as a deliberate transformation of the political and economic position of the university in its relationship to its own members and to the communities each serves.

\subsection{University as a Corporate Entity}

A corporation is a legal convention in which a group of people are legally authorized to act as a single entity. Within the context of business, corporations usually take the form of companies wherein the board of directors are given central authority to act on behalf of combined shareholders. This structure is usually hierarchical in form, with the shareholders only able to exercise control by voting on issues related to Board composition or abandoning the 
company by withdrawing their financial stakes. Similarly, within monopolised commodity markets, customers and consumers have limited economic and social power within this arrangement because their recourse is constrained to boycotts or other consumerist political actions (Zizek, 2017).

Within the context of higher education, a similar power imbalance between central administration and faculty members, or between the institution and students, is contrary to established governance structures. Universities did not adopt corporate-style restructuring on their own, but rather, through a series of governmental decisions, were forced to accept "increasing application of business practices to them as if they were for-profit corporations" (Thornton, 2014, p.2). Within a corporate model of governance, strict hierarchies are enforced in order for the centralised, collective well-being of the institution to be supported. Managers and boards of directors (regents) hold sway because they conceive of themselves as bearing responsibility for accomplishment of the institutional mission. There is also an underlying justification for centralisation in the form of efficiency and the need for perpetual transformation. Universities employ similar justifications to undermine faculty councils and collegial governance models because such democratic institutions are inconvenient; their functioning takes time (Aronowitz, 2000). The need to be able to respond quickly to fickle market trends requires a greater degree of flexibility from central administration than shared governance allows.

Corporate-inspired keywords are those that evoke ambition, concerns with rankings, and a sense of competitive gaming in the race to the top. Words such as "innovation" or "showcasing" appear in this regard, showing desire for being recognized as the best, promoting brand recognition, and innovation, generating or forging new paths being the means allowing the university to launch ahead of the competition. Not only do these keywords establish the university as a competitor in global higher education markets, but they also express the need for universities to prove their value to the societies that subsume them. It is possible to see the ideological twisting and turning that universities must engage in to prove that they are productive, and therefore valuable, institutions globally and locally. Also consistent with corporate images are ill-concealed references to corporate espionage and the protection of corporate secrets. Reminiscent of trade secrets that give particular corporations an economic advantage over their competitors are references to protecting ideas, licensing, stakeholders, and the rush of innovative products to markets ahead of the competition.

Table 1. University as corporate entity

\begin{tabular}{|c|c|c|c|}
\hline University Name & Quote & Location & Keywords \\
\hline Université Laval & $\begin{array}{l}\text { "We will promote the dissemination of innovation in all its forms. The } \\
\text { University will act as a hub for innovation connecting the academic } \\
\text { and research community with the broader community. This will allow it } \\
\text { to develop its research and educational facilities while showcasing the } \\
\text { many concrete benefits they offer." }\end{array}$ & $\begin{array}{l}\text { https://www.ulaval.ca/en/about-us/stra } \\
\text { tegic-plan/engagement.html }\end{array}$ & $\begin{array}{l}\text { dissemination of } \\
\text { innovation, } \\
\text { showcasing, hub for } \\
\text { innovation }\end{array}$ \\
\hline Université Laval & $\begin{array}{l}\text { "As an efficient, modern, and transparent institution, Université Laval } \\
\text { strives for excellence in all facets of its mission, management, and } \\
\text { administration. By hinging our actions on collaborative networks and } \\
\text { practices, we will pool our most effective tools to maximize } \\
\text { administrative efficiency. Such efforts to optimize Université Laval } \\
\text { will allow us focus on bolstering our fundamental mission of teaching, } \\
\text { research, and knowledge transfer. Driven by our quest for excellence, } \\
\text { this collaborative shift will contribute to the transformation of the } \\
\text { academic and research experience and generate more opportunities for } \\
\text { members of the university community to engage with society." }\end{array}$ & $\begin{array}{l}\text { https://www.ulaval.ca/en/about-us/stra } \\
\text { tegic-plan/excellence.html }\end{array}$ & $\begin{array}{l}\text { efficient, transparent, } \\
\text { excellence, tools, } \\
\text { maximize, efficiency, } \\
\text { optimize, bolstering, } \\
\text { knowledge transfer, } \\
\text { transformation, } \\
\text { generate }\end{array}$ \\
\hline McGill University & $\begin{array}{l}\text { "Increasing the emphasis on innovation in all its forms - social, } \\
\text { pedagogical, and organizational as well as through the development of } \\
\text { new products and processes - allows us to play a leading role in a } \\
\text { knowledge-based society. We invent and we increase the impact of } \\
\text { research by translating the results into social and commercial } \\
\text { applications. This translation can take many forms - communicating } \\
\text { research discoveries to decision-makers, transferring knowledge and } \\
\text { know-how, protecting ideas and inventions, licensing discoveries, and } \\
\text { creating new spin-off companies or non-profit organizations." }\end{array}$ & https://mcgill.ca/research/srp & $\begin{array}{l}\text { leading role, impact, } \\
\text { social/commercial } \\
\text { applications, licensing, } \\
\text { protecting ideas, } \\
\text { transferring knowledge }\end{array}$ \\
\hline
\end{tabular}




\begin{tabular}{|c|c|c|c|}
\hline $\begin{array}{l}\text { McMaster } \\
\text { University }\end{array}$ & $\begin{array}{l}\text { "It is critically important that we monitor our progress as we work to } \\
\text { build on our world-leading research enterprise. Resting on our laurels } \\
\text { is not an option if we are to retain-indeed, increase-our status in the } \\
\text { global rankings. Simply put, we need to be at the top of our game. } \\
\text { Ensuring that we perform at our best will require effective and reliable } \\
\text { methods by which we can measure ourselves against our peers. We will } \\
\text { develop a series of metrics to allow us to extract relevant and useful } \\
\text { data about our research progress, compare ourselves to peer } \\
\text { institutions, and evaluate the results of our efforts by department, } \\
\text { faculty, and at an institutional level. }\end{array}$ & $\begin{array}{l}\text { https://macdrive.mcmaster.ca/d/a57b2 } \\
\text { 9dfb7444a3b8c4b/files/?p=/McMaster } \\
\text { \%20Strategic\%20Research\%20Plan\% } \\
\text { 20Full\%202018-2023.pdf, p. } 23\end{array}$ & $\begin{array}{l}\text { enterprise, status, } \\
\text { rankings, game, } \\
\text { perform, measure, } \\
\text { metrics, extract (data), } \\
\text { progress, compare, } \\
\text { evaluate }\end{array}$ \\
\hline University of Ottawa & $\begin{array}{l}\text { "The University of Ottawa ("University") is committed to the support of } \\
\text { research and scholarship that generates new knowledge. It is important } \\
\text { that the results of research at the University be made available to society } \\
\text { in a form which facilitates the maximum utilization of these results. } \\
\text { The University recognizes that, in some cases, technology transfer is } \\
\text { best achieved through patenting or through commercialization } \\
\text { activities in a manner consistent with both the public interest and the } \\
\text { role and image of the University." }\end{array}$ & $\begin{array}{l}\text { https://www.uottawa.ca/administratio } \\
\text { n-and-governance/policy-29-invention } \\
\text {-and-technology-transfer }\end{array}$ & $\begin{array}{l}\text { generates, maximum } \\
\text { utilization, } \\
\text { commercialization, } \\
\text { image }\end{array}$ \\
\hline $\begin{array}{l}\text { University of } \\
\text { Waterloo }\end{array}$ & $\begin{array}{l}\text { "No ivory tower, this is an institution uniquely connected to the world, } \\
\text { and committed to making it better - by fuelling prosperity and } \\
\text { improving the human condition. this is a place of constant forward } \\
\text { motion. A magnet for the best and brightest from around the world, } \\
\text { Waterloo converts the strong into the extraordinary - students who } \\
\text { graduate ready to lead in their careers, faculty who inspire through } \\
\text { world-class teaching, and world-changing research ignited by the } \\
\text { spirit of entrepreneurship. A young institution, Waterloo swiftly } \\
\text { outpaced its national and global peers to rise through the ranks of higher } \\
\text { education. unconventional from the start, Waterloo forges new paths, } \\
\text { redefining higher education as relevant and meaningful. ... University } \\
\text { of Waterloo strategic Plan will create a differentiated university for the } \\
\text { province and the country, one that offers a unique experiential learning } \\
\text { experience for every student; one that focuses on entrepreneurship to } \\
\text { create new companies, new jobs, even new industries... Over the next } \\
\text { five years, on the collective strength of its stakeholders, Waterloo can } \\
\text { and will lead Canada's innovation agenda, redefining higher education } \\
\text { for this country and the world." }\end{array}$ & $\begin{array}{l}\text { https://uwaterloo.ca/strategic-plan/site } \\
\text { s/ca.strategic-plan/files/uploads/files/c } \\
\text { 002637_strategicplan2013.sept3_.low } \\
\text { res_final-s.pdf, p. } 44\end{array}$ & $\begin{array}{l}\text { fueling prosperity, } \\
\text { ignite, spirit of } \\
\text { entrepreneurship, } \\
\text { forges new paths, } \\
\text { excellence, } \\
\text { stakeholders, } \\
\text { innovation agenda }\end{array}$ \\
\hline $\begin{array}{l}\text { University of } \\
\text { Toronto }\end{array}$ & $\begin{array}{l}\text { "U of } \mathrm{T} \text { ignites innovation... Whether } \mathrm{U} \text { of } \mathrm{T} \text { is licensing the } \\
\text { technology or innovation to a start-up company or an existing company, } \\
\text { the goal is to maximize the chances of successfully advancing } \\
\text { products to market while supporting the University's mission of } \\
\text { research and education." }\end{array}$ & $\begin{array}{l}\text { http://www.research.utoronto.ca/wp-c } \\
\text { ontent/uploads/2018/04/18-1-Guidebo } \\
\text { oks-Startup_FINAL.pdf, p. } 4-5\end{array}$ & $\begin{array}{l}\text { ignite, innovation, } \\
\text { maximize, advancing, } \\
\text { products, market }\end{array}$ \\
\hline
\end{tabular}

Also, within this thematic analysis keywords such as "transparency," "rankings" and "metrics" are identified as ways of avoiding or eliminating the hard-won democratic governance structures established by previous generations. The new measure by which university central administrations appear accountable to their constituents is regular reporting of improvements on arbitrary scales, selectively assessing specific aspects of performance. This eliminates the need for dialogue among members of a community and democratic structures established to promote plurality of opinion. Political disagreements are not allowed to disrupt the efficient production of knowledge and are papered over to project a fragile illusion of consensus (Ives, 2004). Thus, the necessary transformation of the collegial governance of the university is further undermined by understanding the market as the de facto democratic institution to which the university is beholden. All that matters for the reconstituted university is its own self-promotion--which justifies the adoption of dehumanised measures to assess the worth of its academic workers and the education that the university provides to students. 
Table 2. Academic identity: students, faculty

\begin{tabular}{|c|c|c|c|}
\hline University Name & Quote & Location & Keywords \\
\hline $\begin{array}{l}\text { The University of } \\
\text { British Columbia }\end{array}$ & $\begin{array}{l}\text { "Excellence: A profound and aspirational value: the } \\
\text { quality of striving to be, and being, outstanding." }\end{array}$ & $\begin{array}{l}\text { https://www.ubc.ca/about/vision-values.ht } \\
\mathrm{ml}\end{array}$ & excellence, striving, outstanding \\
\hline $\begin{array}{l}\text { University of } \\
\text { Calgary }\end{array}$ & $\begin{array}{l}\text { "Lifelong learners, seekers of new knowledge and } \\
\text { innovation, and thought leaders in their respective } \\
\text { disciplines, they have become meaningful contributors } \\
\text { and active citizens, locally and globally. We must } \\
\text { strengthen our connection to this important part of our } \\
\text { community to achieve our vision and create mutual } \\
\text { benefit." }\end{array}$ & $\begin{array}{l}\text { https://www.ucalgary.ca/eyeshigh/progres } \\
\text { s/community-engagement }\end{array}$ & $\begin{array}{l}\text { lifelong learners, thought leaders, } \\
\text { innovation, contributors, active } \\
\text { citizens }\end{array}$ \\
\hline $\begin{array}{l}\text { University of } \\
\text { Calgary }\end{array}$ & $\begin{array}{l}\text { "Our curriculum reflects Calgary's enterprising spirit. It } \\
\text { instills the importance of applying new-found knowledge } \\
\text { to address society's most persistent and emerging } \\
\text { challenges, and teaches students how to explore bold new } \\
\text { approaches. At every opportunity, we show our students } \\
\text { how a research-intensive university accelerates their } \\
\text { personal growth and career trajectory." }\end{array}$ & $\begin{array}{l}\text { https://www.ucalgary.ca/eyeshigh/progres } \\
\text { s/teaching-and-learning }\end{array}$ & $\begin{array}{l}\text { enterprising, bold, personal } \\
\text { growth }\end{array}$ \\
\hline $\begin{array}{l}\text { University of } \\
\text { Calgary }\end{array}$ & $\begin{array}{l}\text { "Great people are our most valuable assets. We will } \\
\text { continue to attract, encourage and recognize talented } \\
\text { students, faculty and post-doctoral scholars who conduct } \\
\text { globally recognized research. ... We commit to increasing } \\
\text { research capacity and creating a dynamic environment to } \\
\text { promote research excellence." }\end{array}$ & $\begin{array}{l}\text { https://www.ucalgary.ca/eyeshigh/progres } \\
\text { s/research-and-scholarship }\end{array}$ & $\begin{array}{l}\text { valuable assets, capacity, } \\
\text { dynamic, excellence }\end{array}$ \\
\hline $\begin{array}{l}\text { University of } \\
\text { Calgary }\end{array}$ & $\begin{array}{l}\text { "Like entrepreneurial thinking, scholarly activity starts } \\
\text { with curiosity, exploration, and openness to new } \\
\text { approaches. And like entrepreneurial thinkers, } \\
\text { academics challenge current thinking, tackle issues with } \\
\text { large-scale implications, spend years testing and } \\
\text { perfecting solutions, and put societal impact first. And } \\
\text { because diversification and resilience can help } \\
\text { recession-proof an economy, it makes sense to develop } \\
\text { graduates who can meet the changing needs of our } \\
\text { community, and who have the skills to adapt and pivot } \\
\text { throughout their careers. By thinking more } \\
\text { entrepreneurially ..., we can help students prepare for } \\
\text { these changes. ... help mid-career professionals re-tool - } \\
\text { teaching them how to interpret, analyze, and apply the } \\
\text { data-driven findings now essential to success in nearly } \\
\text { every industry." }\end{array}$ & https://go.ucalgary.ca/report.html; pg. 4 & $\begin{array}{l}\text { curiosity, exploration, openness, } \\
\text { impact, develop (graduates), } \\
\text { adapt, pivot, re-tool, think } \\
\text { entrepreneurially, resilience, } \\
\text { recession-proof }\end{array}$ \\
\hline $\begin{array}{l}\text { Dalhousie } \\
\text { University }\end{array}$ & $\begin{array}{l}\text { "Our intimate learning environment allows students an } \\
\text { opportunity to engage with award-winning professors. } \\
\text { Our professors take pride in sharing knowledge, research } \\
\text { opportunities and the support you need to reach your full } \\
\text { potential." }\end{array}$ & $\begin{array}{l}\text { https://www.dal.ca/about-dal/academic-ex } \\
\text { cellence.html }\end{array}$ & award-winning, potential \\
\hline Université Laval & $\begin{array}{l}\text { "The entrepreneurs in our community innovate and } \\
\text { participate fully in the development of society. The } \\
\text { University will support an engaged citizenry that } \\
\text { engenders business ideas contributing to sustainable } \\
\text { development, flourishing societies, and better ways of live } \\
\text { together." }\end{array}$ & $\begin{array}{l}\text { https://www.ulaval.ca/en/about-us/strategi } \\
\text { c-plan/engagement.html }\end{array}$ & $\begin{array}{l}\text { entrepreneurs, innovate, } \\
\text { development, contributing }\end{array}$ \\
\hline
\end{tabular}




\begin{tabular}{|c|c|c|c|}
\hline Université Laval & $\begin{array}{l}\text { "Attract and recruit more professors and foster faculty } \\
\text { loyalty to contribute to institutional } \\
\text { development... Nurture the commitment and } \\
\text { contributions of members of the university community } \\
\text { and enhance the university's reputation." }\end{array}$ & $\begin{array}{l}\text { https://www.ulaval.ca/en/research/official- } \\
\text { documents, "2015-2020 Research } \\
\text { Development Plan",pg. } 3\end{array}$ & $\begin{array}{l}\text { loyalty, contribute, development, } \\
\text { contributions, enhance } \\
\text { (reputation) }\end{array}$ \\
\hline McGill University & $\begin{array}{l}\text { "McGill researchers apply their ingenuity and creativity } \\
\text { in service to society. Drawing on the strengths and } \\
\text { expertise of different stakeholders, they co-create and } \\
\text { apply evidence-based research to address shared } \\
\text { challenges; guide and develop policies, practices and } \\
\text { products; provide innovative learning environments and } \\
\text { professional experiences for students at all levels; improve } \\
\text { professional practices; and seek out and support initiatives } \\
\text { that result in tangible improvements for individuals and } \\
\text { communities." }\end{array}$ & https://mcgill.ca/research/srp & $\begin{array}{l}\text { ingenuity, creativity, stakeholders, } \\
\text { apply, innovative, initiatives, } \\
\text { tangible }\end{array}$ \\
\hline $\begin{array}{l}\text { University of } \\
\text { Saskatchewan }\end{array}$ & $\begin{array}{l}\text { “... we need to harness scholarly strength, creativity, and } \\
\text { inventiveness across our campus - which means that we } \\
\text { will need to acknowledge and tackle unevenness in the } \\
\text { quality of research, learning, teaching, and citizenship } \\
\text { within our disciplines. } \\
\text { Uncompromising cultivation of disciplinary depth is } \\
\text { essential to preparing the university for sustainable } \\
\text { leadership in interdisciplinary research, scholarship, and } \\
\text { creative pursuits in the future. ... The measure of our } \\
\text { success lies in attracting and retaining top talent, } \\
\text { competing successfully for external resources and } \\
\text { partnerships, and ensuring readiness and appetite to } \\
\text { contribute to the university's larger collaborative and } \\
\text { interdisciplinary efforts.” }\end{array}$ & $\begin{array}{l}\text { https://plan.usask.ca/boundless-collaborati } \\
\text { on.php }\end{array}$ & $\begin{array}{l}\text { harness, strength, creativity, } \\
\text { inventiveness, unevenness, } \\
\text { cultivation, leadership, measure, } \\
\text { top talent, competing }\end{array}$ \\
\hline $\begin{array}{l}\text { McMaster } \\
\text { University }\end{array}$ & $\begin{array}{l}\text { "McMaster's research strength is one of the University's } \\
\text { most prized assets. Home to some of the best minds and } \\
\text { research facilities in the country, with research output } \\
\text { rivalling universities more than twice its size, McMaster } \\
\text { has a well-deserved reputation as a crucible of discovery } \\
\text { and innovation." }\end{array}$ & $\begin{array}{l}\text { (McMaster University; } \\
\text { https://research.mcmaster.ca/about-researc } \\
\text { h-mcmaster) }\end{array}$ & $\begin{array}{l}\text { Prized assets, discovery, } \\
\text { innovation, output }\end{array}$ \\
\hline $\begin{array}{l}\text { McMaster } \\
\text { University }\end{array}$ & $\begin{array}{l}\text { "We find answers to complex problems across a wide } \\
\text { range of disciplines and support innovative thinkers who } \\
\text { are eager to share their ideas in a spirit of openness, } \\
\text { inclusiveness and collaboration." }\end{array}$ & $\begin{array}{l}\text { (McMaster University; } \\
\text { https://brand.mcmaster.ca/our-story/) }\end{array}$ & innovative \\
\hline $\begin{array}{l}\text { Queen's } \\
\text { University }\end{array}$ & $\begin{array}{l}\text { "One of the top universities in Canada, Queen's is home to } \\
\text { leading researchers making a real and measured impact. } \\
\text { The university provides a dynamic living and learning } \\
\text { environment where scientists, philosophers, artists, and } \\
\text { scholars of all kinds share ideas, push the boundaries of } \\
\text { what's known and understood, and ultimately, make an } \\
\text { unmistakable impact on the world." }\end{array}$ & https://www.queensu.ca/research/about & $\begin{array}{l}\text { leading, measured, impact, } \\
\text { dynamic, impact, push boundaries }\end{array}$ \\
\hline $\begin{array}{l}\text { Queen's } \\
\text { University }\end{array}$ & $\begin{array}{l}\text { "We are researchers, scholars, artists, professors and } \\
\text { students with an ambitious spirit who want to develop } \\
\text { ideas that can make a difference in the world. People who } \\
\text { imagine together what the future could be and work } \\
\text { together to realize it." }\end{array}$ & https://www.queensu.ca/about/quickfacts & ambitious, develop \\
\hline
\end{tabular}




\begin{tabular}{|c|c|c|c|}
\hline $\begin{array}{l}\text { Queen's } \\
\text { University }\end{array}$ & $\begin{array}{l}\text { "Instructors at Queen's continue to innovate in course and } \\
\text { program delivery by piloting new instructional } \\
\text { approaches, explicitly developing and assessing learning } \\
\text { outcomes, and incorporating educational technology, and } \\
\text { incorporating active learning strategies in the } \\
\text { classroom." }\end{array}$ & $\begin{array}{l}\text { https://www.queensu.ca/sites/default/files/ } \\
\text { assets/pages/strategicframework/Teaching } \\
\text { AndLearningActionPlanMarch2014.pdf, p. } \\
6\end{array}$ & innovate, incorporating \\
\hline $\begin{array}{l}\text { University of } \\
\text { Toronto }\end{array}$ & $\begin{array}{l}\text { "We believe that excellence flourishes in an environment } \\
\text { that embraces the broadest range of people, that helps them } \\
\text { to achieve their full potential, that facilitates the free } \\
\text { expression of their diverse perspectives through respectful } \\
\text { discourse, and in which high standards are maintained for } \\
\text { students and staff alike. An equitable and inclusive } \\
\text { working and learning environment creates the conditions } \\
\text { for our diverse staff and student body to maximize their } \\
\text { creativity and their contributions, thereby supporting } \\
\text { excellence in all dimensions of the institution." }\end{array}$ & https://www.utoronto.ca/about-u-of-t & $\begin{array}{l}\text { Excellence flourishes, potential, } \\
\text { achieve, maximize, creativity, } \\
\text { contribution }\end{array}$ \\
\hline $\begin{array}{l}\text { University of } \\
\text { Toronto }\end{array}$ & $\begin{array}{l}\text { "The University of Toronto (U of } \mathrm{T} \text { ) is where research } \\
\text { excellence comes together with a collaborative, } \\
\text { entrepreneurial spirit. U of T entrepreneurs tackle global } \\
\text { challenges and solve real-world problems." }\end{array}$ & $\begin{array}{l}\text { http://www.research.utoronto.ca/wp-conte } \\
\text { nt/uploads/2018/04/18-1-Guidebooks-Start } \\
\text { up_FINAL.pdf, p. } 2\end{array}$ & $\begin{array}{l}\text { excellence, entrepreneurial spirit, } \\
\text { entrepreneurs }\end{array}$ \\
\hline $\begin{array}{l}\text { University of } \\
\text { Toronto }\end{array}$ & $\begin{array}{l}\text { "Building on our world class research excellence and } \\
\text { exceptional talent, our rich community of } \\
\text { entrepreneurship incubators and accelerators is } \\
\text { creating the innovative companies and jobs of the future. } \\
\text { The University of Toronto Entrepreneurship community } \\
\text { provides mentorship, expertise, resources, and strategic } \\
\text { connections for all stages of the innovation pipeline to } \\
\text { give entrepreneurs the skills and resources they need to } \\
\text { effectively start, build and scale their businesses." }\end{array}$ & http://entrepreneurs.utoronto.ca/about/ & $\begin{array}{l}\text { excellence, rich, entrepreneurship } \\
\text { accelerators/incubators, } \\
\text { innovative, innovation pipeline }\end{array}$ \\
\hline $\begin{array}{l}\text { University of } \\
\text { Waterloo }\end{array}$ & $\begin{array}{l}\text { "Springing from Waterloo's unique history is a strong } \\
\text { culture of innovation and a can-do attitude in its } \\
\text { students, faculty and staff. A tradition of incorporating } \\
\text { relevance and applicability into teaching and research } \\
\text { programs is inspired by Waterloo's longstanding } \\
\text { commitment to meet the intellectual and practical } \\
\text { challenges that arise from societal change. A strong track } \\
\text { record of engagement with industry - evolving from } \\
\text { co-op and continuing through its research programs - } \\
\text { fosters an innovative and entrepreneurial culture." }\end{array}$ & $\begin{array}{l}\text { https://uwaterloo.ca/strategic-plan/sites/ca. } \\
\text { strategic-plan/files/uploads/files/c002637_ } \\
\text { strategicplan2013.sept3_.lowres_final-s.pd } \\
\text { f, p. } 8\end{array}$ & $\begin{array}{l}\text { culture of innovation, can-do } \\
\text { attitude, entrepreneurial culture }\end{array}$ \\
\hline
\end{tabular}

\subsection{Aspirational Academic Identities}

This theme of identity construction within the academy has two features leading to an overall commodification of higher education as the intentional obliteration of the human intersubjective relationship creating both education and research (Marx, 1977). Childress (2019) articulated this commodity form for both research and education, suggesting that universities are based on a value extraction model, paying contract academic staff a fraction of the fees paid by students in order to maximise profit without any additional infrastructure expenditures. The purpose of this commodity form within neoliberalism is to devalue the work of staff and faculty in order to pay them less and profit more.

The first move in this analysis through the Marxian theory of commodity fetishism is to consider education an act of consumption. Students are reimagined through this construction as they are consumers of education and are presented with aspirational outcomes such as "leadership," "entrepreneurial spirit," "talent" or "excellence" deriving from their consumption. Such students are not learning humanistic values that will serve them as morally sound, just, or kind people, or as community members with a disposition toward service to others. Instead, education serves a 
strictly personal, individual purpose where the end consumer (the student) can leverage certification in order to lead, or dominate, their communities.

The second feature contributing to this theme is production. Faculty are identified as producers of value within the commodified university. Student success is attributable to the institutional success of a university, useful for further self-promotion. An example comes from the website of Université Laval:

The entrepreneurs in our community innovate and participate fully in the development of society. The University will support an engaged citizenry that engenders business ideas contributing to sustainable development, flourishing societies, and better ways of live together. (emphasis added)

Faculty are the main productive agents within the self-promotion of the neoliberal university, most often manifested commodified and dehumanized research producers. Research, and the people who conduct it, are positioned as "assets" to be exploited, used to improve ratings when competing within the higher education international marketplace. Furthermore, research is frequently explicitly promoted for commercial value or utility, a commodity of social and economic capital. Less often referenced is teaching as a productive enterprise, but it does emerge when quality of instruction is considered. Interpersonal relationships with professors and course instructors are also positioned as a consumer good, intended to be used to maximize potential.

This division of humans within these institutions into the categories of consumer and producer contributes to the radical destruction of communal and democratic governance referenced above. Instructors and researchers are reduced to interchangeable parts in the institution of higher learning, part of which means identifying academic identities metaphorically with contradictory, sometimes oxymoronic, growth and birth metaphors: Incubate; "cultivates a pipeline of creators"; "cultivates human potential"; foster; cultivating "disciplinary depth." Students are reimagined as either consumers or human potential to be cultivated.

Through this method of self-promotion universities are able to justify the social and economic devaluation of academic work in order for institutions to pursue profit, often on the backs of increasingly precariously-employed academic workers (Childress, 2019). Further, the students are not free in this marketplace to choose for themselves academic or social aspirations; they must become self-actualised in a particular mould as conquerors and serfs simultaneously, able to lead their fellows after graduation because of their willingness to first submit to the centralised authority of a bureaucratised administrative apparatus.

Table 3. University as machine or vehicle

\begin{tabular}{|c|c|c|c|}
\hline University Name & Quote & Location & Keywords \\
\hline $\begin{array}{l}\text { University of } \\
\text { Manitoba }\end{array}$ & $\begin{array}{l}\text { "In } 2017 / 18 \text {, U of M research received a record } \$ 211.7 \text { million in } \\
\text { research funding. As Manitoba's only research-intensive university, } \\
\text { we fuel the local economy and enhance our community’s } \\
\text { successes." }\end{array}$ & $\begin{array}{l}\text { https://umanitoba.ca/about/factan } \\
\text { dfigures/\#innovative-teaching }\end{array}$ & fuel, enhance \\
\hline $\begin{array}{l}\text { University of } \\
\text { Alberta }\end{array}$ & $\begin{array}{l}\text { "Driving the future via knowledge, discovery and innovation: One } \\
\text { of Canada's top five research universities, we are a research and } \\
\text { innovation hub that is helping create tomorrow today." }\end{array}$ & https://www.ualberta.ca/research/ & $\begin{array}{l}\text { driving, innovation, } \\
\text { discovery }\end{array}$ \\
\hline $\begin{array}{l}\text { Dalhousie } \\
\text { University }\end{array}$ & $\begin{array}{l}\text { "Dalhousie is Atlantic Canada's idea engine for a knowledge-based } \\
\text { economy." }\end{array}$ & $\begin{array}{l}\text { https://www.dal.ca/about-dal/wor } \\
\text { ld-class-research/industry-and-inn } \\
\text { ovation.html) }\end{array}$ & idea engine \\
\hline $\begin{array}{l}\text { Dalhousie } \\
\text { University }\end{array}$ & $\begin{array}{l}\text { "Dalhousie cultivates a pipeline of creators, innovators and } \\
\text { entrepreneurs and empowers students and faculty to create local and } \\
\text { global impact. Our approach to innovation is broad, and includes the } \\
\text { creativity needed to generate new ideas and the entrepreneurial } \\
\text { mindset needed to take a risk and apply those new ideas." }\end{array}$ & $\begin{array}{l}\text { https://dalinnovates.ca/about-2/in } \\
\text { novation-and-entrepreneurship-at } \\
\text {-dalhousie/ }\end{array}$ & $\begin{array}{l}\text { cultivates, pipeline, } \\
\text { empowers, impact, } \\
\text { entrepreneurial } \\
\text { mindset, take a risk }\end{array}$ \\
\hline Université Laval & $\begin{array}{l}\text { "The power of a university community driven by a network-based } \\
\text { approach....A new dynamic of cooperation between units, faculties, } \\
\text { and departments for greater efficiency in the pursuit of our } \\
\text { mission... Modern tools to streamline the flow of knowledge.... } \\
\text { Leveraging the synergy between the university community and its } \\
\text { many partners to enhance our academic and research offerings." }\end{array}$ & $\begin{array}{l}\text { https://www.ulaval.ca/en/about-u } \\
\text { s/strategic-plan/projects.html\#c46 } \\
1391\end{array}$ & $\begin{array}{l}\text { network, dynamic, } \\
\text { efficiency, leveraging, } \\
\text { streamline, synergy, } \\
\text { enhance }\end{array}$ \\
\hline
\end{tabular}




\begin{tabular}{|c|c|c|c|}
\hline $\begin{array}{l}\text { University of } \\
\text { Toronto }\end{array}$ & $\begin{array}{l}\text { "Founded in 1827, the University of Toronto has evolved into } \\
\text { Canada's leading institution of learning, discovery and knowledge } \\
\text { creation. We are proud to be one of the world's top } \\
\text { research-intensive universities, driven to invent and innovate." }\end{array}$ & $\begin{array}{l}\text { https://www.utoronto.ca/about-u- } \\
\text { of-t }\end{array}$ & $\begin{array}{l}\text { knowledge creation, } \\
\text { driven, invent, } \\
\text { innovate }\end{array}$ \\
\hline $\begin{array}{l}\text { McMaster } \\
\text { University }\end{array}$ & $\begin{array}{l}\text { "At McMaster, we are devoted to the cultivation of human } \\
\text { potential. We are committed to taking a collaborative approach to } \\
\text { improving people's lives, contributing to global knowledge and } \\
\text { finding creative solutions to some of our most complex challenges. } \\
\text { One of the ways we fulfill this commitment is by pioneering } \\
\text { groundbreaking research in fields ranging from health care to } \\
\text { business, arts and culture to advanced manufacturing. We're } \\
\text { empowering the next generation to create a Brighter World." }\end{array}$ & $\begin{array}{l}\text { (McMaster University; } \\
\text { https://brand.mcmaster.ca/) }\end{array}$ & $\begin{array}{l}\text { Cultivation of human } \\
\text { potential, pioneering, } \\
\text { empowering, create }\end{array}$ \\
\hline $\begin{array}{l}\text { University of } \\
\text { Saskatchewan }\end{array}$ & $\begin{array}{l}\text { "This animating premise and driver of accountability has three } \\
\text { implications. First, we will do as much as we can to achieve the } \\
\text { greatest possible impact for our communities - we can never rest, } \\
\text { allow ourselves to feel satisfied that we've done enough or } \\
\text { become complacent about the complex process of translating } \\
\text { discoveries into results for communities. Second, in order to } \\
\text { demonstrate that our value claims are genuine, we will work hard as a } \\
\text { university community to quantify, document, and defend the } \\
\text { impact to which our research, scholarly, and artistic efforts are } \\
\text { contributing-evidence of impact is both a moral obligation and a } \\
\text { growing expectation of the partners and communities that } \\
\text { support and work with us. Finally, we need to be very clear as a } \\
\text { university community about when and how we can help to create the } \\
\text { greatest value and commit energy and resources to realizing this } \\
\text { potential." }\end{array}$ & $\begin{array}{l}\text { https://plan.usask.ca/inspired-com } \\
\text { munities.php }\end{array}$ & $\begin{array}{l}\text { Driver of } \\
\text { accountability, impact, } \\
\text { never rest/never } \\
\text { satisfied, complacent, } \\
\text { translating discoveries } \\
\text { into results, quantify, } \\
\text { document, defend, } \\
\text { evidence, expectations, } \\
\text { partners, potential }\end{array}$ \\
\hline $\begin{array}{l}\text { McMaster } \\
\text { University }\end{array}$ & $\begin{array}{l}\text { "University research is the foundation of knowledge. It is the driver } \\
\text { of innovation and critical to the social, cultural and economic fabric } \\
\text { of our society. Research is the tool that supports evidence-based } \\
\text { decisions - decisions that inform policy, impact organizations, and } \\
\text { influence the lives of citizens locally and globally." }\end{array}$ & $\begin{array}{l}\text { https://macdrive.mcmaster.ca/d/a } \\
\text { 57b29dfb7444a3b8c4b/files/?p=/ } \\
\text { McMaster\%20Strategic\%20Rese } \\
\text { arch\%20Plan\%20Full\%202018-2 } \\
\text { 023.pdf, p. } 1\end{array}$ & $\begin{array}{l}\text { driver, innovation, } \\
\text { evidence-based } \\
\text { decisions, impact }\end{array}$ \\
\hline $\begin{array}{l}\text { McMaster } \\
\text { University }\end{array}$ & $\begin{array}{l}\text { "McMaster's commitment to research excellence is informed by a set } \\
\text { of core values from which we will not waver: } \\
\text { • } . \text { W We conduct research that advances society, using the } \\
\text { best practices and cutting-edge technologies } \\
\text { - We support collaborative work and thinking ... as an } \\
\text { essential driver of innovation. } \\
\text { We partner with hospitals, governments, institutions, and } \\
\text { businesses locally, nationally, and globally to share } \\
\text { resources and expertise, solve complex problems, spur } \\
\text { economic growth, and create a more skilled } \\
\text { workforce." }\end{array}$ & $\begin{array}{l}\text { https://macdrive.mcmaster.ca/d/a } \\
\text { 57b29dfb7444a3b8c4b/files/?p=/ } \\
\text { McMaster\%20Strategic\%20Rese } \\
\text { arch\%20Plan\%20Full\%202018-2 } \\
\text { 023.pdf, p. } 4\end{array}$ & $\begin{array}{l}\text { advances, driver, } \\
\text { innovation, spur } \\
\text { (economic) growth, } \\
\text { skilled workforce, } \\
\text { cutting-edge }\end{array}$ \\
\hline $\begin{array}{l}\text { Queen's } \\
\text { University }\end{array}$ & $\begin{array}{l}\text { “Queen's University has } 175+\text { years of shaping Canada's future - } \\
\text { through innovation and impact as a leader in higher education, } \\
\text { research and knowledge mobilization.” }\end{array}$ & $\begin{array}{l}\text { https://www.queensu.ca/strategic } \\
\text { planning/research }\end{array}$ & $\begin{array}{l}\text { innovation, impact, } \\
\text { knowledge } \\
\text { mobilization }\end{array}$ \\
\hline $\begin{array}{l}\text { Queen's } \\
\text { University }\end{array}$ & $\begin{array}{l}\text { "The Queen's environment is a catalyst that challenges and supports, } \\
\text { in equal measure, the balance of innovative research with excellence } \\
\text { in teaching to provide a dynamic living and learning environment - } \\
\text { an environment where exceptional people create an unrivalled } \\
\text { community and an unmatched mix of opportunities for discovery, } \\
\text { collaboration, and partnership." }\end{array}$ & $\begin{array}{l}\text { https://www.queensu.ca/strategic } \\
\text { planning/research }\end{array}$ & $\begin{array}{l}\text { catalyst, innovative, } \\
\text { dynamic }\end{array}$ \\
\hline
\end{tabular}




\subsection{University as Machine or Vehicle}

Furthering metaphorical uses of ideologically-laden language are repeated references to the university as a type of machine which requires fuel, has an engine which drives its aims and productive output, or that uses its social impact in order to develop networks of synergistic knowledge production to increase global impact and reach. We find vehicle or driving metaphors such as fuels, drives, propels, accelerates, as well as imagery relating to a forward sense of progress: Advance[ing], enhance, transforming, driving the future, evolve/evolution, adapt/pivot, develop, improve, mobilize, catalyze, stimulate, dynamic, particularly those which also emphasize the brutal, lethal, force of advance, like cutting, carving out, and pushing boundaries. These keywords and catch phrases are not limited to any specific institution, but are illustrative of the ways that both analogue and digital mechanistic metaphors are used in order to position the university in relation to its desired consumer (i.e. the student) and to sterilise the university's self-image as a place where production happens. A pristine, cold, institutionalised knowledge factory (Aronowitz, 2000), an "idea engine" is projected for the self-promotion of the university and the economic productivity of its surrounding community.

The position of the university is clear relative to the student, it is a "pipeline" which provides the student with access to skills, networks; it fosters an "entrepreneurial mindset" among its graduates. Students need universities to act as brokers for their aspirations; universities have crafted a standardised mechanism for producing these outcomes. The main features by which the university sells itself to prospective students seem to be the rapidity and/or flexibility of available services, clear in references to driving or fuelling innovation or discovery. Students are encouraged to decide whether or not the university is the most efficient means by which they can reach these promised aspirational goals.

A final note is that many machines are hostile to human life if humans were to try and survive within them or around them. Machines are typically used in production in order to replace human labour with objects capable of withstanding high heat, toxic environments, or better able to engage in repetitive motion that would injure humans. However, this is likely a deliberate omission; the metaphorical transformation of the university into a machine is not intended to betray the often-inhospitable working and learning conditions that it produces.

Table 4. Market metaphors

\begin{tabular}{|c|c|c|c|}
\hline University Name & Quote & Location & Keywords \\
\hline $\begin{array}{l}\text { University of } \\
\text { Manitoba }\end{array}$ & $\begin{array}{l}\text { "Researchers engaging in Indigenous scholarship } \\
\text { communicate knowledge in innovative ways, employing } \\
\text { cutting-edge methodologies to improve the lives of } \\
\text { Indigenous peoples locally, nationally, and globally." }\end{array}$ & $\begin{array}{l}\text { https://umanitoba.ca/research/index. } \\
\text { html }\end{array}$ & $\begin{array}{l}\text { innovative, employing, } \\
\text { cutting-edge }\end{array}$ \\
\hline $\begin{array}{l}\text { University of } \\
\text { Calgary }\end{array}$ & $\begin{array}{l}\text { "We have an ambitious roadmap to achieve our research } \\
\text { vision. It matches our strengths with opportunities, } \\
\text { increases our research capacity, creates a dynamic } \\
\text { environment to promote research excellence, and } \\
\text { embraces both curiosity-driven and solution-oriented } \\
\text { research. Bolstered by positive feedback from our } \\
\text { community about our research priorities and the } \\
\text { investments we made in research infrastructure, we } \\
\text { will continue our commitment to sharpen our focus on } \\
\text { research and scholarship." }\end{array}$ & $\begin{array}{l}\text { https://www.ucalgary.ca/eyeshigh/p } \\
\text { rogress/research-and-scholarship }\end{array}$ & $\begin{array}{l}\text { ambitious, capacity, } \\
\text { dynamic, excellence, } \\
\text { curiosity-driven, } \\
\text { solution-oriented, } \\
\text { priorities, investments, } \\
\text { infrastructure }\end{array}$ \\
\hline $\begin{array}{l}\text { University of } \\
\text { Calgary }\end{array}$ & $\begin{array}{l}\text { "Society benefits when scholars focus their collective } \\
\text { effort in areas of strength. We create synergies that } \\
\text { energize our researchers around issues that are globally } \\
\text { relevant and of great importance to our stakeholder } \\
\text { communities. We demonstrate leadership in areas of } \\
\text { strength and monitor all areas of the academy for } \\
\text { emerging ideas. We will also refine the ways in which we } \\
\text { measure the impact of our work and share our } \\
\text { scholarship." }\end{array}$ & $\begin{array}{l}\text { https://www.ucalgary.ca/eyeshigh/p } \\
\text { rogress/research-and-scholarship }\end{array}$ & $\begin{array}{l}\text { synergies, stakeholder, } \\
\text { leadership, measure, } \\
\text { impact }\end{array}$ \\
\hline Dalhousie & "Our focus on academic innovation means we are & https://www.dal.ca/about-dal/acade & innovation, development, \\
\hline
\end{tabular}




\begin{tabular}{|c|c|c|c|}
\hline University & $\begin{array}{l}\text { committed to the continuous development of our } \\
\text { programs and courses, how they are designed, and how } \\
\text { we deliver them." }\end{array}$ & mic-excellence.html & design, deliver \\
\hline $\begin{array}{l}\text { Dalhousie } \\
\text { University }\end{array}$ & $\begin{array}{l}\text { "To create a hub of world-leading research and } \\
\text { innovation, adding to the intellectual, social and } \\
\text { economic capital of our communities." }\end{array}$ & $\begin{array}{l}\text { https://www.dal.ca/research/Resear } \\
\text { chVisionMissionandValues.html }\end{array}$ & $\begin{array}{l}\text { innovation, capital } \\
\text { (intellectual, social, } \\
\text { economic) }\end{array}$ \\
\hline $\begin{array}{l}\text { Dalhousie } \\
\text { University }\end{array}$ & $\begin{array}{l}\text { "Equity, diversity and inclusiveness (EDI) are firmly } \\
\text { implanted within Dalhousie's strategic priorities. The } \\
\text { university has introduced a wide-reaching Diversity \& } \\
\text { Inclusiveness Strategy, which includes initiatives } \\
\text { focused on employment equity. The Research and } \\
\text { Innovation Enterprise at Dalhousie will propel research } \\
\text { and innovation excellence across all disciplines, fully } \\
\text { aligned with the university's EDI goals." }\end{array}$ & $\begin{array}{l}\text { https://www.dal.ca/research/Resear } \\
\text { chVisionMissionandValues.html }\end{array}$ & $\begin{array}{l}\text { implanted, strategic, } \\
\text { initiatives, propel, } \\
\text { innovation, excellence }\end{array}$ \\
\hline $\begin{array}{l}\text { Dalhousie } \\
\text { University }\end{array}$ & $\begin{array}{l}\text { "As a leading innovative, research-intensive university } \\
\text { offering a wide variety of innovation and } \\
\text { entrepreneurship programming, including academic } \\
\text { courses, programs, research and extra-curricular } \\
\text { activities, Dalhousie both supports and plays a leadership } \\
\text { role in the innovation and entrepreneurship } \\
\text { ecosystem." }\end{array}$ & $\begin{array}{l}\text { https://www.dal.ca/research/Resear } \\
\text { chEnterpriseatDalhousie.html }\end{array}$ & $\begin{array}{l}\text { innovative/innovation, } \\
\text { entrepreneurship }\end{array}$ \\
\hline $\begin{array}{l}\text { Dalhousie } \\
\text { University }\end{array}$ & $\begin{array}{l}\text { "We will drive impact through translational research } \\
\text { and innovation, leveraging research to drive social, } \\
\text { cultural and economic development." }\end{array}$ & $\begin{array}{l}\text { https://www.dal.ca/research/Strategi } \\
\text { cImplementationGoals.html }\end{array}$ & $\begin{array}{l}\text { drive, impact, leveraging, } \\
\text { development }\end{array}$ \\
\hline $\begin{array}{l}\text { Dalhousie } \\
\text { University }\end{array}$ & $\begin{array}{l}\text { "Dalhousie supports the translation of important new } \\
\text { ideas into innovations effectively, efficiently and } \\
\text { expediently through its commercialization services to } \\
\text { maximize the quality and volume of potentially } \\
\text { important innovations for society. This approach takes a } \\
\text { much broader view of returns to the university, by not } \\
\text { focusing on short-term revenue from licensing, but the } \\
\text { long-term social and economic impact, and the resulting } \\
\text { virtuous cycle of reputational rewards that will create } \\
\text { much greater value for the university and our local, } \\
\text { national and global communities." }\end{array}$ & $\begin{array}{l}\text { https://dalinnovates.ca/about-2/inno } \\
\text { vation-and-entrepreneurship-at-dalh } \\
\text { ousie/ }\end{array}$ & $\begin{array}{l}\text { effectively, efficiently, } \\
\text { expediently, maximize, } \\
\text { returns/revenue, } \\
\text { innovations, impact, } \\
\text { reputational rewards, } \\
\text { value }\end{array}$ \\
\hline $\begin{array}{l}\text { Queen's } \\
\text { University }\end{array}$ & $\begin{array}{l}\text { "Queen's recognizes that the teaching and learning } \\
\text { landscape is shifting in exciting new directions and if we } \\
\text { are to remain successful in providing the ultimate } \\
\text { transformative student learning experience, we must } \\
\text { continue to identify and implement new opportunities } \\
\text { that build on our strong foundations. This work is } \\
\text { achieved through innovative solutions, such as active } \\
\text { and collaborative learning techniques, rethinking } \\
\text { classroom spaces, and implementing alternative program } \\
\text { delivery methods to better reflect the opportunities of } \\
\text { the digital age. We are also working to expand the } \\
\text { diversity of credentials, as well as experiential and } \\
\text { entrepreneurial learning opportunities that will foster } \\
\text { the skills needed for our students to be successful in } \\
\text { today's increasingly diverse labour market." }\end{array}$ & $\begin{array}{l}\text { https://www.queensu.ca/provost/tea } \\
\text { ching-and-learning) }\end{array}$ & $\begin{array}{l}\text { transformative, } \\
\text { innovative, delivery } \\
\text { methods, experiential, } \\
\text { entrepreneurial, foster, } \\
\text { successful, labour market }\end{array}$ \\
\hline
\end{tabular}




\subsection{Market Metaphors}

There has been a pronounced trend within the last 40 years to see the market as the primary means through which we can effectively govern ourselves and democratise our societies (Ball, 2006). This emerges from the market liberalism popularised in the U.S. by Milton Friedman and in the rest of the world by Friedrich Hayek (Ayers, 2005). This asserted itself most visibly with the elections of Margaret Thatcher in the U.K. and Ronald Reagan in the U.S. Describing the relationship between the political and economic philosophies of Hayek with Thatcherism in Britain, Ball (2006) argued

According to Hayek, government failure is more common and more likely than economic failure. The market embodies a superior rationality. Governments once embarked upon social or economic expenditure programmes are confronted by and susceptible to interest and client group pressures for more or new expenditures. And elections are imperfect public choice mechanisms, they encourage governments to attempt to buy support. (Ball, 2006, p.36)

Thatcher, Reagan, Clinton, Blair, and other world leaders who followed them subscribed to this political and economic philosophy. It can be observed in the keywords highlighted in this theme in the way that markets are referred to as rationally structuring the institutions of higher education: Enrich, impact/impactful, maximize, optimize, produce/productive/products, the research enterprise, enterprising, invest, measurable/tangible, mutual or concrete benefits, incorporate, profitability/prosperity, stakeholders, resources/assets (often describing people/groups), leveraging, delivery, potential, flexible, capital, outcomes, strategic, capacity, performance, value, efficient/efficiency, apply/applications, competitiveness, accountability, synergistic, exploit/extract/appropriate.

Within university marketisation, order is structured so that words such as "innovation", "drive", and "entrepreneur" are used to portray the solitary academic or student, self-interested and rationally making choices to sell themselves in a globally competitive marketplace. Words such as "leverage" are used in place of "dominate", "deceive", "hoard", or "dispossess" which are the actual tools by which the most successful entrepreneurs, as eventual rentiers, relate to others in a competitive marketplace (Holborow, 2015). Research is considered based on its economic impact; the university is an employer (its primary contribution to the wider community); the student is buying a leg up within an increasingly stark labour market. Like the other themes, the apparent purpose of the market metaphor appears to be to absolve institutions, governments, and people of their collective responsibilities. Society itself, by engaging in service to one's community, is irrational and not self-interested. The intersubjective relationship between people is reimagined as being mitigated by market exchanges between rational actors as the highest order of freedom.

Market interactions within neoliberal discourses are not biased in the same way that collectivist discourses are, given that the idealised decentralization of economic and political control within markets makes them less subject to concentrated excesses of power like those found when governments are charged with certain tasks. Immune from the same forces of direct manipulation that democratic institutions are, markets are positioned as a preferred way of discursively structuring the exchange of goods and power between people. Constituting higher education in this way potentially justifies centralised administration within a greater number of offices and legal departments producing more strictly authoritarian control mechanisms in public spaces, a condition Ball (2006) labels "new managerialism". Disruptions to the reputational aspirations of the university, for instance, could negatively affect its competitiveness within the marketplace and thus undermine the entire collective enterprise. Potential disruption therefore needs to be managed by bureaucrats and lawyers, removed from interference by democratic processes.

Table 5. The doctrine of discovery

\begin{tabular}{|c|c|c|c|}
\hline University Name & Quote & Location & Keywords \\
\hline $\begin{array}{l}\text { University of } \\
\text { Manitoba }\end{array}$ & $\begin{array}{l}\text { "Fueled by curiosity, our researchers are deciphering the building } \\
\text { blocks of life, creating profound expressions of culture and } \\
\text { discovering innovations that will shape the world of tomorrow." }\end{array}$ & $\begin{array}{l}\text { https://umanitoba.ca/about/factandfi } \\
\text { gures/\#our-students/ }\end{array}$ & $\begin{array}{l}\text { curiosity, fueled, } \\
\text { discovering, } \\
\text { innovations }\end{array}$ \\
\hline $\begin{array}{l}\text { University of } \\
\text { Manitoba }\end{array}$ & $\begin{array}{l}\text { "Advancing the University's commitment to embed Indigenous } \\
\text { perspectives into learning, discovery and engagement, eight new } \\
\text { Indigenous scholars have joined the U of M in 2018. Joining more than } \\
30 \text { others who work across the university, they will enhance our } \\
\text { classrooms across disciplines and help create pathways to } \\
\text { Indigenous knowledge and achievement." }\end{array}$ & $\begin{array}{l}\text { https://umanitoba.ca/about/factandfi } \\
\text { gures/\#innovative-teaching }\end{array}$ & $\begin{array}{l}\text { discovery, create } \\
\text { pathways }\end{array}$ \\
\hline
\end{tabular}




\begin{tabular}{|c|c|c|c|}
\hline $\begin{array}{l}\text { University of } \\
\text { Alberta }\end{array}$ & $\begin{array}{l}\text { "From making discoveries that answer fundamental questions to } \\
\text { building new businesses and industries, to improving human health } \\
\text { and fostering social change, our researchers are at the forefront of } \\
\text { advancing knowledge for the benefit of all." }\end{array}$ & https://www.ualberta.ca/research/ & $\begin{array}{l}\text { discoveries, } \\
\text { building, fostering, } \\
\text { at the forefront, } \\
\text { advancing }\end{array}$ \\
\hline $\begin{array}{l}\text { The University of } \\
\text { British Columbia }\end{array}$ & $\begin{array}{l}\text { "Since 1915, our motto, Tuum Est (It is Yours), has been a declaration } \\
\text { of our commitment to attracting and supporting those who have the } \\
\text { drive to shape a better world. As a result, UBC students, faculty and } \\
\text { staff continue to embrace innovation and challenge the status quo, } \\
\text { placing us at the forefront of discovery, learning and engagement. } \\
\text { UBC encourages bold thinking, curiosity and initiative, so you can } \\
\text { realize your greatest potential." }\end{array}$ & https://www.ubc.ca/about/ & $\begin{array}{l}\text { drive, innovation, } \\
\text { challenge, forefront, } \\
\text { discovery, bold } \\
\text { thinking, curiosity, } \\
\text { initiative, potential }\end{array}$ \\
\hline $\begin{array}{l}\text { University of } \\
\text { Calgary }\end{array}$ & $\begin{array}{l}\text { "Through research programs and strategic partnerships, we pursue } \\
\text { knowledge, contribute to the development and critique of societal } \\
\text { goals, and spark innovation." }\end{array}$ & $\begin{array}{l}\text { https://www.ucalgary.ca/eyeshigh/p } \\
\text { rogress/research-and-scholarship }\end{array}$ & $\begin{array}{l}\text { spark, innovation, } \\
\text { pursue, strategic, } \\
\text { contribute }\end{array}$ \\
\hline $\begin{array}{l}\text { University of } \\
\text { Calgary }\end{array}$ & $\begin{array}{l}\text { "Our students and faculty conduct basic and applied research at the } \\
\text { frontiers of knowledge and transfer this knowledge to society - } \\
\text { locally, regionally, nationally and internationally. We will actively } \\
\text { support our research community in releasing new findings, } \\
\text { implementing important advancements and presenting } \\
\text { thought-provoking creative works." }\end{array}$ & $\begin{array}{l}\text { https://www.ucalgary.ca/eyeshigh/p } \\
\text { rogress/research-and-scholarship }\end{array}$ & $\begin{array}{l}\text { frontiers, transfer, } \\
\text { implementing, } \\
\text { advancements }\end{array}$ \\
\hline $\begin{array}{l}\text { University of } \\
\text { Calgary }\end{array}$ & $\begin{array}{l}\text { "UCalgary is on a mission to discover new knowledge and translate } \\
\text { our discoveries into applications that provide benefits to our } \\
\text { communities." }\end{array}$ & https://research.ucalgary.ca/ & $\begin{array}{l}\text { discover, } \\
\text { applications, } \\
\text { benefits }\end{array}$ \\
\hline $\begin{array}{l}\text { Dalhousie } \\
\text { University }\end{array}$ & $\begin{array}{l}\text { "Founded in } 1818 \text {, we're one of Canada's oldest universities, attracting } \\
\text { more than } 19,000 \text { students from around the world. We make a lasting } \\
\text { impact by blending transformative academic programs with } \\
\text { pioneering research on Canada's East Coast." }\end{array}$ & https://www.dal.ca/about-dal.html & $\begin{array}{l}\text { transformative, } \\
\text { pioneering, impact }\end{array}$ \\
\hline $\begin{array}{l}\text { Dalhousie } \\
\text { University }\end{array}$ & $\begin{array}{l}\text { "Chairholders advance the frontiers of knowledge in their fields, not } \\
\text { only through their own work, but also by teaching and supervising } \\
\text { students and coordinating the work of other researchers." }\end{array}$ & $\begin{array}{l}\text { https://www.dal.ca/about-dal/world- } \\
\text { class-research.html }\end{array}$ & $\begin{array}{l}\text { advance, frontiers } \\
\text { (of knowledge) }\end{array}$ \\
\hline $\begin{array}{l}\text { Dalhousie } \\
\text { University }\end{array}$ & $\begin{array}{l}\text { "It is a strategy grounded in discovery, innovation and impact, } \\
\text { designed to ensure that our research activities have an even stronger } \\
\text { influence on the local, regional and global landscape." }\end{array}$ & https://www.dal.ca/research.html & $\begin{array}{l}\text { discovery, } \\
\text { innovation, impact }\end{array}$ \\
\hline McGill University & $\begin{array}{l}\text { "Our Mission: To support and enhance a cohesive university-wide } \\
\text { environment of research excellence where faculty are inspired and } \\
\text { challenged to push the boundaries of knowledge creation. } \\
\text { Our Vision: To be the premier research-intensive university in } \\
\text { Canada and to be seen as a key partner in the development and } \\
\text { advancement of national and international research and technology } \\
\text { initiatives. To be leaders in the creation of a research environment that } \\
\text { is second to none globally for the advancement of socially relevant } \\
\text { research that dominates the world stage." }\end{array}$ & $\begin{array}{l}\text { https://mcgill.ca/research/about/mis } \\
\text { sion }\end{array}$ & $\begin{array}{l}\text { excellence, premier, } \\
\text { push the boundaries, } \\
\text { advancement, } \\
\text { leaders, dominates, } \\
\text { knowledge creation }\end{array}$ \\
\hline $\begin{array}{l}\text { University of } \\
\text { Saskatchewan }\end{array}$ & $\begin{array}{l}\text { "The first commitment of our plan is Courageous Curiosity. It } \\
\text { challenges us to empower a daring culture of innovation with the } \\
\text { courage to confront humanity's greatest challenges and } \\
\text { opportunities with four distinct goals: } \\
\text { - Unleash Discovery } \\
\text { - Uplift Indigenization } \\
\text { - Embrace Interdisciplinarity } \\
\text { - Seek Solutions" }\end{array}$ & $\begin{array}{l}\text { https://plan.usask.ca/courageous-cur } \\
\text { iosity.php }\end{array}$ & $\begin{array}{l}\text { courage, curiosity, } \\
\text { daring, confront, } \\
\text { challenges, } \\
\text { opportunities, } \\
\text { unleash, uplift, } \\
\text { discovery, seek }\end{array}$ \\
\hline $\begin{array}{l}\text { Université de } \\
\text { Montréal }\end{array}$ & $\begin{array}{l}\text { "It supports research by affirming its primary objective: the discovery, } \\
\text { advancement, and mobilization of knowledge." }\end{array}$ & $\begin{array}{l}\text { https://recherche.umontreal.ca/filea } \\
\text { dmin/recherche/documents/user_upl } \\
\text { oad_ancien/La_recherche_a_UdeM/ }\end{array}$ & $\begin{array}{l}\text { discovery, } \\
\text { advancement, } \\
\text { mobilization (of }\end{array}$ \\
\hline
\end{tabular}




\begin{tabular}{|c|c|c|c|}
\hline & & $\begin{array}{l}\text { Fichiers/Strategic_plan_research_2 } \\
017-2021 \_ \text {avril.pdf; p. } 6\end{array}$ & knowledge) \\
\hline $\begin{array}{l}\text { Université de } \\
\text { Montréal }\end{array}$ & $\begin{array}{l}\text { "1. Affirm the positioning of UdeM as a powerful vector of } \\
\text { discovery, creation, and innovation..." }\end{array}$ & $\begin{array}{l}\text { https://recherche.umontreal.ca/filea } \\
\text { dmin/recherche/documents/user_upl } \\
\text { oad_ancien/La_recherche_a_UdeM/ } \\
\text { Fichiers/Strategic_plan_research_2 } \\
\text { 017-2021_avril.pdf; p. } 13\end{array}$ & $\begin{array}{l}\text { powerful, vector, } \\
\text { discovery, creation, } \\
\text { innovation }\end{array}$ \\
\hline $\begin{array}{l}\text { University of } \\
\text { Waterloo }\end{array}$ & $\begin{array}{l}\text { "Waterloo goes beyond the classroom, to a place where experience is } \\
\text { the teacher. Beyond problems to solutions that address social, technical } \\
\text { and economic needs. Beyond the laboratory, to the research that } \\
\text { propels industries, organizations and society. Waterloo is at the } \\
\text { forefront of innovation and is home to transformational research } \\
\text { and inspired learning. Located in the heart of Canada's technology hub, } \\
\text { we are growing a network of global partnerships that will shape the } \\
\text { future by working beyond disciplines and building bridges with } \\
\text { industry, institutions and communities. Our incredible people and } \\
\text { partners take us beyond the lives we're living today, to find solutions to } \\
\text { the global challenges that lie ahead. Creating change that goes beyond } \\
\text { the status quo and is felt around the world. Waterloo goes beyond-to } \\
\text { challenge, connect and propel our world." }\end{array}$ & https://uwaterloo.ca/about/ & $\begin{array}{l}\text { propels, forefront of } \\
\text { innovation, } \\
\text { transformation }\end{array}$ \\
\hline $\begin{array}{l}\text { University of } \\
\text { Waterloo }\end{array}$ & $\begin{array}{l}\text { "Consistently ranked Canada's most innovative university, Waterloo } \\
\text { champions a culture of curiosity, exploration, risk-taking, } \\
\text { entrepreneurship, global stewardship and leadership. We bring } \\
\text { bold ideas and brilliant minds together - inspiring innovations with } \\
\text { global impact today and in the future." }\end{array}$ & $\begin{array}{l}\text { https://uwaterloo.ca/about/who-we- } \\
\text { are }\end{array}$ & $\begin{array}{l}\text { innovative, } \\
\text { curiosity, } \\
\text { exploration, } \\
\text { entrepreneurship, } \\
\text { stewardship, } \\
\text { leadership, bold, } \\
\text { innovations, impact }\end{array}$ \\
\hline $\begin{array}{l}\text { University of } \\
\text { Waterloo }\end{array}$ & $\begin{array}{l}\text { "We aim to be the world's top university for creators, explorers and } \\
\text { boundary-pushing thinkers." }\end{array}$ & $\begin{array}{l}\text { https://uwaterloo.ca/about/who-we- } \\
\text { are/rankings }\end{array}$ & $\begin{array}{l}\text { creators, explorers, } \\
\text { boundary-pushing }\end{array}$ \\
\hline $\begin{array}{l}\text { University of } \\
\text { Waterloo }\end{array}$ & $\begin{array}{l}\text { "For almost } 60 \text { years, the University of Waterloo has been advancing } \\
\text { knowledge through outstanding scholarship and landmark research to } \\
\text { address major challenges arising from the intersection of social, } \\
\text { scientific, technological, environmental, health, and policy issues. } \\
\text { Innovation is at the core of Waterloo and characterizes the } \\
\text { University's research. Groundbreaking research has fuelled new ideas } \\
\text { and technologies, and research excellence across all six Faculties } \\
\text { continues to foster a vigorous spirit of discovery and knowledge } \\
\text { mobilization." }\end{array}$ & $\begin{array}{l}\text { https://uwaterloo.ca/research/sites/c } \\
\text { a.research/files/uploads/files/accessi } \\
\text { ble_c008348-research-stratplan_7.7 } \\
\text { 5x10_lowres_final.pdf, p. } 1\end{array}$ & $\begin{array}{l}\text { advancing } \\
\text { knowledge, } \\
\text { innovation, fueled, } \\
\text { excellence, } \\
\text { vigorous, spirit of } \\
\text { discovery, } \\
\text { knowledge } \\
\text { mobilization }\end{array}$ \\
\hline $\begin{array}{l}\text { University of } \\
\text { Alberta }\end{array}$ & $\begin{array}{l}\text { "Within a vibrant and supportive learning environment, the University } \\
\text { of Alberta discovers, disseminates and applies new knowledge } \\
\text { through teaching and learning, research and creative activity, } \\
\text { community involvement and partnerships. The U of A gives a national } \\
\text { and international voice to innovation in our province, taking a lead } \\
\text { role in placing Canada at the global forefront." }\end{array}$ & https://www.ualberta.ca/about & $\begin{array}{l}\text { discovers, applies, } \\
\text { innovation, lead role }\end{array}$ \\
\hline $\begin{array}{l}\text { University of } \\
\text { Alberta }\end{array}$ & $\begin{array}{l}\text { "Within a vibrant and supportive learning environment, the University } \\
\text { of Alberta discovers, disseminates and applies new knowledge } \\
\text { through teaching and learning, research and creative activity, } \\
\text { community involvement and partnerships. The U of A gives a national } \\
\text { and international voice to innovation in our province, taking a lead } \\
\text { role in placing Canada at the global forefront." }\end{array}$ & https://www.ualberta.ca/about & $\begin{array}{l}\text { discovers, applies, } \\
\text { innovation }\end{array}$ \\
\hline
\end{tabular}




\subsection{Doctrine of Discovery}

The final theme addresses the outward focus of the university as it attempts to dominate local and international higher education markets on a hierarchy of competing institutions. Within this "doctrine of discovery" the university sanctions its members (students, researchers, alumni, staff, faculty, etc.), to act in a certain way in regards to the rest of the world. They are bold, daring, courageous, ambitious, leaders, while they carve their own paths, innovate, discover, generate, create pathways, venture, "advance the frontiers of knowledge", dominate, pioneer, push boundaries, explore - at the forefront [globally]. The university is simultaneously a portal through which young professionals can be trained in order to colonise their fellows, a venue for the collection and selective distribution of knowledge products to help inform these well-trained envoys of the enclosures of late capitalism, and also a place which legitimises people to explore Terra Nullius and extract from her the wealth of her natural and human resources.

(De)colonisation is a counter metaphor useful in considering the discursive function of discovery within these "virtual faces" of the university (Wilson \& Meyer, 2009). Use of notions of the "frontier", "cutting-edge", "boundaries", and the ways that Indigenous knowledges are constructed as a virgin field for exploitation all reinforce the extractive (Kouritzin \& Nakagawa, 2018) way that knowledge accumulation is marketed as a social good for the assimilation of people and resources within the sterile confines of the university. Unbound by local, regional, or national concerns, possibly as a result of technological developments which make international partnerships more cheaply feasible, the modern university is conceived of as being able to arrive in any region, mine the local knowledges of the people, package it into neatly conceived packages to be re-sold to others. Smith (2012) describes how researchers have long treated Indigenous peoples as features of the natural environment to be mined and written about, on whom many academics have built lucrative careers without ever giving back to the communities.

More transparent perhaps, is the prominence of commercial and economic concerns as the central justification for discovery. There is little pretence of a humanist or humanitarian outlook; rather, discovery appears valued only insofar as it can "propel industries, organizations, and society" (University of Waterloo). No care seems to be given to the direction to which the university is propelling society, only that it must use its engines to go somewhere. The people who are trampled underfoot this rudderless propulsion are not consultative partners in the pursuit of discovery. Partnerships are considered mainly with institutions recognisable to the university, that is, other universities, businesses, or governments. Fraser and Honneth (2003) recognize this as a problem of political thought; persons not embedded within a community cannot understand the political landscape nor the purchase of certain voices within it. They have knowledge only at a distance, via imperfect forms of publicly-available communication.

\section{Limitations and Future Research}

This study is not an exhaustive analysis of university websites in Canada. Our findings result from the analyses of four individuals, all of them positioned within one university in the U15, either as faculty or graduate students. Our research questions were limited to an examination of discourse strategies on university websites, and what those textual choices suggest about academic identities, institutional aims, and the public alignment of universities with prevailing ideologies and socio-political values.

We suggest that these websites align universities with the values of consumer and petro-capitalism rather than with the traditional university ideals of intellectual pursuit, knowledge creation, disciplinary wisdom, and rigorous scholarship. We suggest that university websites communicate and foster neoliberal discourses, ideologies, values, and identities that impact our everyday working lives in ways that can be documented. We have shown that U15 university websites use machine and petroleum-metaphors to promote themselves, but we have not yet begun to examine where those carbon-fueled vehicles are going. We have pointed to how websites perpetuate colonial Terra Nullius and doctrine of discovery myths. On the other hand, what we have not done or have left for further research, is examine how university websites portray images of inclusion, diversity and equity-seeking groups based on age, binary and non-binary gender, sex and sexuality, social roles, imagined communities, legitimate participation, racialized characteristics, Indigeneity, performance and dress, social class, disability, language or ethnicity.

We have unpacked how the university is positioned as a corporation, and how the academics within the institution are its entrepreneurs, but we have not addressed who university websites are written for--presumably stakeholders, funders, government agencies, and perhaps, more peripherally, parents and their 17-year olds choosing ideal universities. We have not examined the construction of university employees who are not faculty members or those who are not permanent faculty members, the representations of the university as a physical or social space, nor have we delved into reasons for the noteworthy absence of the core mission of teaching in the university (Jawitz \& Williams, 2015; Blanco \& Metcalfe, 2020). We have not examined how university websites present universities as 
employers, in the global bidding war to attract world class professors and researchers. We have not questioned why, when universities are competing for both students and capital, they use remarkably similar marketing strategies and metaphors on their websites, establishing distinctions of degree rather than real, visible distinctions in programs, outlook, and values. Nor have we dealt with metaphor itself. We have only just begun.

\section{Acknowledgment}

This work was supported by the Social Sciences and Humanities Research Council of Canada (SSHRC), Insight Grant number 435-2019-0808. The authors would like to thank SSHRC for their support; any errors or omissions belong entirely to the authors. We have no conflicts of interest.

\section{References}

Aronowitz, S. (2000). The Knowledge Factory: Dismantling the Corporate University and Creating True Higher Learning. Boston, Mass: Beacon Press.

Ayers, D. F. (2005). Neoliberal Ideology in Community College Mission Statements: A Critical Discourse Analysis. The Review of Higher Education, 28(4), 527-549. https://doi.org/10.1353/rhe.2005.0033.

Ball, S. J. (2006). Education Policy and Social Class: The selected works of Stephen J. Ball. London, UK: Routledge.

Ball, S. J. (2012). Performativity, commodification and commitment: An I-spy guide to the neoliberal university. British Journal of Educational Studies, 60(1), 17-28. https://doi.org/10.1080/00071005.2011.650940

Blanco, G. L., \& Metcalfe, A. (2020). Visualizing quality: University online identities as organizational performativity in Higher Education. The Review of Higher Education, 43(3), 781-809. https://doi.org/10.1353/rhe.2020.0007

Boyer, L., Brunner, B. R., Charles, T., \& Coleman, P. (2006). Managing Impressions in a Virtual Environment: Is Ethnic Diversity a Self-Presentation Strategy for Colleges and Universities?. Journal of Computer-Mediated Communication, 12, 136-154. https://doi.org/10.1111/j.1083-6101.2006.00318.x

Chatterton, P., Hodkinson, S., \& Pickerill, J. (2010). Beyond scholar activism: Making strategic interventions inside and outside the neoliberal university. ACME: An International E-Journal for Critical Geographies, 9(2), 245-275.

Childress, H. (2019). The Adjunct Underclass: How America's Colleges Betrayed their Faculty, their Students, and their Mission. Chicago, Ill: Chicago University Press.

Fairclough, N. (2010). Critical discourse analysis: The critical study of language (2nd ed.). New York, NY: Routledge.

Fairclough, N. (2013). Language and power (3rd ed.). New York, NY: Routledge.

Fraser, N., \& Honneth, A. (2003). Redistribution or Recognition? A political-philosophical exchange. New York, NY: Verso.

Gabel, S. L., Reid, D., Ruiz, H., \& Hume-Dawson, R. (2016). Disability and Diversity on CSU Websites: A Critical Discourse Study. Journal of Diversity in Higher Education, 9(1), 64-80. https://doi.org/10.1037:a0039256

Hoang, T. V. Y., \& Rojas-Lizana, I. (2015). Promotional discourse in the websites of two Australian universities: A discourse analytic approach. Cogent Education, 2(1), 1-19. https://doi.org/10.1080/2331186X.2015.1011488

Holborow, M. (2015). Language and Neoliberalism. London, UK: Routledge.

Ihme, T. A., Sonnenberg, K., Barbarino, M., Fisseler, B., \& Stürmer, S. (2016). How University Websites' Emphasis on Age Diversity Influences Prospective Students' Perception of Person-Organization Fit and Student Recruitment. Research in Higher Education, 57, 1010-1020. https://doi.org/10.1007/s11162-016-9415-1

Ives, P. (2004). Language and hegemony in Gramsci. London, UK: Pluto Press.

Jawitz, J., \& Williams, K. (2015). Presence and Absence: Looking for Teaching and Teach Development in the Website of a 'Research-led' South African University. Critical Studies in Teaching \& Learning, 3(1), 44-60. https://doi.org/10.114425/cristal.v3i1.41

Kimmons, R. (2017). Open to all? Nationwide evaluation of high-priority web accessibility considerations among higher education websites. Journal of Computing in Higher Education, 29, 434-450. https://doi.org/10.1007/s12528-017-9151-3 
Kouritzin, S. (2019). Extent and consequences of 'workload creep' in three Faculties of Education, Canadian Journal of Education, 42(4), 1092-1120.

Kouritzin, S., \& Nakagawa, S. (2018). Toward a sustainable, non-extractive research ethics for cross cultural, cross-linguistic research. Journal of Multicultural and Multilingual Development, 39, 675-687. https://doi.org/10.1080/01434632.2018.1427755

Kouritzin, S., Kolomic, E., Ellis, T. F., \& Nakagawa, S. (2020). Academic Dignity: Countering the Emotional Experience of Academia. Canadian Journal of Educational Administration and Policy, in press.

Kouritzin, S., Nakagawa, S., Ellis, T. F., \& Kolomic, E. (2021, June). Neoliberal sleight of hand in a University strategic plan: Weaponized sustainability, strategic absences, and magic time. The Alberta Journal of Educational Research (accepted), forthcoming.

Marx, K. (1977). Capital: A critique of political economy. New York, NY: Vintage Books.

Massey, D. (2013). Vocabularies of the economy. Soundings: A Journal of Politics and Culture, 54, 9-22.

Peters, M. A. (2013). Managerialism and the neoliberal university: Prospects for new forms of "open management" in higher education. Contemporary Readings in Law and Social Justice, 1, 11-26.

Saichaie, K. (2011). Representation on college and university websites: An approach using critical discourse analysis (Doctoral dissertation). University of Iowa. Retrieved from http://ir.uiowa.edu/etd/1071

Smith, L. T. (2012). Decolonizing methodologies: Research and indigenous peoples (2nd ed.). London, UK: Zed Books.

Smyth, J. (2017). The toxic university: Zombie leadership, academic rock stars and neoliberal ideology. London, UK: Palgrave Macmillan.

Sutton, P. (2017). Lost souls? The demoralization of academic labour in the measured university. Higher Education Research \& Development, 36(3), 625-636. https://doi.org/10.1080/07294360.2017.1289365

Tongtong, Z. (2017). The Marketization of Higher Education Discourse: A Genre Analysis of University Website Homepages in China. Higher Education Studies, 7(3), 64-79. https://doi.org/10.5539/hes.v7n3p64

Tuchman, G. (2009). Wannabe U: Inside the Corporate University. Chicago: University of Chicago Press.

Verkijika, S. F., \& De Wets, L. (2020). Accessibility of South African university websites. Universal Access in the Information Society, 19, 201-210. https://doi.org/10.1007/s10209-018-0632-6

Wilson, J. L., \& Meyer, K. A. (2009). Higher education websites: The "virtual face" of diversity. Journal of Diversity in Higher Education, 2(2), 91-102. https://doi.org/10.1037/a0015443

Zhang, Y., \& O'Halloran, K. L. (2013). 'Toward a global knowledge enterprise': university websites as portals to the ongoing marketization of higher education. Critical Discourse Studies, 10(4), 468-485. https://doi.org/10.1080/17405904.2013.813777

Zizek, S. (2017). In Defense of Lost Causes. Brooklyn, NY: Verso.

\section{Copyrights}

Copyright for this article is retained by the author(s), with first publication rights granted to the journal.

This is an open-access article distributed under the terms and conditions of the Creative Commons Attribution license (http://creativecommons.org/licenses/by/4.0/). 